\title{
Is the Tax Burden a Generating Factor of Fiscal Evasion in South-East Europe?
}

\section{Loredana Andreea Cristea, Alina Daniela Vodă, Bianca Ciocanea, and Mihaela Luca}

Lucian Blaga University of Sibiu, Department of Doctoral Studies, Victoria Boulevard 10, Sibiu, Romania

\section{Abstract}

Tax evasion is a pernicious phenomenon, very widespread in the world, which is closely linked to the system of taxes and fees. This is considered to be a response to the excessive fiscal pressure exerted on taxpayers. Bypassing the law is also closely related to the phenomenon of corruption and its removal is a difficult target, under the existing conditions. The main purpose of this paper is to study the influence of corruption and fiscal pressure on the phenomenon of tax evasion, materialized by the shadow economy indicator. The analysis is carried out over a period of 18 years, namely 1999-2016, for six countries of South-Eastern Europe, member states of the

Corresponding Author: Loredana Andreea Cristea crs.loredana@yahoo.com

Received: 17 November 2019 Accepted: 6 January 2019 Published: 12 January 2020

Publishing services provided by Knowledge E

(c) Loredana Andreea Cristea et al. This article is distributed under the terms of the

commons Attribution License, which permits unrestricted use and redistribution provided that the original author and source are credited.

Selection and Peer-review unde the responsibility of the EBEEC Conference Committee. European Union, divided into two categories, namely developed and emerging states. The research methodology requires comparative analysis of existing situations in the research countries. Also, we will use the econometric analysis, with the help of statistical package for social sciences, of the relationship between the underground economy and corruption, as well as the correlation between tax burden exerted by the budget revenues and tax evasion. Being difficult to quantify, the level of shadow economy has been taken from Friedrich Schneider's studies, through which he measured underground economy in 157 countries over the period 1999-2013; but also in 36 states, between 2003 and 2016. The level of corruption is measured using the corruption perception index at international level and the tax burden is calculated as the ratio between tax revenue and gross domestic product.

Keywords: tax burden, shadow economy, corruption, South-East Europe.

JEL Classification: H2, H26, E62.

\section{Introduction}

Tax burden influences taxpayer compliance and directly influences the occurrence of tax evasion phenomenon. In recent years, this phenomenon has been increasingly studied, in order to find ways to mitigate the negative effects it leaves behind, such as decreases in state revenues. Corruption, at national level, may be a factor in encouraging the evasion element. At the same time, the existence of high fiscal pressure creates an optimal environment for action, for those who are working in the shadow economy, but 
also for those who, due to high tax constraints, appeal either to tax avoidance or to tax evasion, so to obtain a relaxation, from the fiscal point of view.

In this study it will be take into account the definition on which Schneider [27] has carried out its numerous studies on tax evasion and on the quantification of the shadow economy. This definition takes into account those activities hidden deliberately to any of the following reasons:

1. To avoid payment of income tax, value added tax or other taxes;

2. To avoid paying social security contributions;

3. To avoid having to meet certain labor market legal standards, such as minimum wages, working hours, safety standards etc.;

4. To avoid certain administrative procedures, such as filling in statistical questionnaires or other administrative forms.

A first objective of this research is the quantitative study of fiscal pressure, corruption and tax evasion in the six countries selected from the South-Eastern European Union, in order to delineate the situation of emerging countries as compared to the situation of developed countries. The second objective of the research is the qualitative study on the correlation between the fiscal pressure and the two pernicious phenomena with negative effects on the economic and financial area.

The question of the study, that seeks to get an answer, is related to the manner and the extent to which the tax burden exerted in a country influences the development of the shadow economy and corruption. The way through this question is answered is by using the Statistical Package for Social Sciences (SPSS).

The first part of the paper includes the study of the literature review on tax evasion, corruption and the results obtained in previous researches. Then follows the comparative study of the tax burden related to the budget revenues, the study of the shadow economy's evolution, as a percentage of the gross domestic product (GDP), as well as the study of the corruption perception index (CPI), at the level of researched countries. The second part of the paper includes the analysis of the influence relationship between the corruption and shadow economy, as well as between the fiscal pressure and shadow economy. Finally, it is intended to highlight the extent to which high tax burden represent or not represent a determinant and encouraging factor for tax evasion. 


\section{Literature Review}

The phenomenon of tax evasion has been extensively studied over time, both in terms of its underlying determinant factors, but also from a conceptually and structurally point of view. Although this phenomenon is extensively researched, because it is difficult to observe it, there are no official statistics on this issue and it has to be estimated by indirect approaches. The biggest problem regarding tax evasion or shadow economy refers to the hidden nature of this phenomenon, although there are estimates and assumptions about its size.

The hidden sector of the economy includes the size of the shadow economy and that of tax evasion, which, although they are not alike, they overlap [26]. Activities in the underground economy often involve the avoidance of direct or indirect taxes, so that the factors affecting tax evasion will directly affect the shadow economy as well.

It is recognized in the literature that the most important cause that encourages the shadow economy is the tax burden experienced by taxpayers. However, there are other generating factors that lead to the development of this phenomenon, such as the unemployment rate, the economic freedom index, the regulatory burden, the rate of independent activities [17], but also the tax burden on taxes and social contributions, the quality of public institutions, public services and the degree of economic development [27]. Numerous studies have been also conducted on the determinants of this phenomenon, among which we can recall: low tax morale, low ability to detect those who practice fiscal evasion, culture and public awareness of the population [15, 16], low quality of life, imperfect fiscal legislation, aggressive taxation policies [30], the level of poverty, corruption [4], government efficiency, rule of law [18], employment rate, income inequality and gender-based wage gap [25].

The shadow economy can be divided into 4 types, namely the illegal economy (such as drug trafficking, smuggling etc.), undeclared economy (activities undertaken to avoid established tax rules), unregistered economy (activities that are not recorded in official statistics) and the informal economy (activities that violate administrative rules) [24]

In the current economy, there are two terms used, which are often used in the same sense, namely tax avoidance and tax evasion. However, these are different. The phenomenon of tax avoidance refers to the taxpayer's ability to use the lack of legal provisions [5]; to avoid paying the budgetary obligations, in whole or in part, by exploiting 'loopholes' of the law [9]; but also to extend as far as possible the interpretation of what is legal to minimize the overall tax contribution of the company. 
The European Commission defines the tax avoidance as being: "the acting within the law, sometimes at the edge of legality, to minimize or eliminate tax that would otherwise be legally owed. It often involves exploiting the strict letter of the law, loopholes and mismatches to obtain a tax advantage that was not originally intended by the legislation"[11].

Some companies exploit the legal loopholes in existing tax systems and the existing inconsistencies, to avoid paying the equitable tax rate. Moreover, the tax regimes of several countries allow companies to transfer profits artificially to their jurisdictions. A measure to reduce this type of licit tax evasion within multinational companies may be by the transfer pricing files.

The phenomenon of tax evasion refers to the taxpayer's action to directly violate the legal provisions, for example by not declaring taxable material, by using fictitious payment documents, by false accounting records, account compensations, undeclared activities or income etc.[1, 4]. The definition of the European Commission on the phenomenon of tax evasion refers generally to: "illegal arrangements where tax liability is hidden or ignored, for example, the taxpayer pays less tax than he/she is supposed to pay under the law, by hiding income or information from the tax authorities" [11].

These terms are also used in the literature as legal/licit and illegal/illicit tax evasion. But this conception is erroneous, since the term of evasion has itself the significance of breaking the law. In Romanian law, respectively on Law no. 241/2005 there is no definition of tax evasion, being only stipulated in Article 9, those acts committed for the purpose of avoiding the tax obligations, which constitute tax evasion crimes and are punished with imprisonment from 2 years to 8 years [20].

Closely related to tax evasion, being an element that may favor the evasion of payment, it is also corruption. Corruption has many forms, such as bribery, influence peddling, abuse of functions, but it can also hide behind nepotism, conflicts of interest etc. and it is a threat to countries, in many ways [12]. Although the nature and magnitude of corruption may vary from one Member State to another, it affects the European Union $(E U)$ as a whole, by lowering the level of investment, preventing the proper functioning of the internal market and reducing public finances.

Over time, more research has been done on the link between tax evasion, corruption and the determinants of these broad phenomena. For example, Braşoveanu [6] through the study of the negative relationship between tax revenues and corruption, concluded that in the Latin, Balkan and Baltic countries this phenomenon is at large scale, with a high level in emerging countries and with an alarming tendency of growing in developed countries. Through its studies at a global level, Virta [31, 32] noted that there 
is a substitution link between the shadow economy and corruption, with a negative correlation in tropical countries, because bribes are being used in this region for public servants, in order to stay in the registered economy.

An interesting result of a research is that happiness and wealth are the main determinants of the size of the shadow economy in the European Union's countries. It is more important to measure the emotional prosperity of a nation, than its economic prosperity [2]. Concerning the negative consequences of evasion and corruption, they are reflected in the discouragement of entrepreneurial activities [3], social stratification, reduction of public revenues, unfair competition, slowing down the economic growth, and as regards the positive consequences of the fiscal evasion and corruption, they contribute to the reduction of social tensions, by a certain improvement of the living standards of those with low incomes, and economically it prevents the decrease of the profit rate [14].

In order to remove, stop, prevent or minimize the phenomenon of tax evasion in Romania, Cărăuș et al. [7] proposed the following measures: "reducing bureaucracy, implementing lifelong training programs for public servants, reducing waiting time at the counter, introducing modern payment systems, the development of IT applications aimed at identifying the taxpayer profile, as well as the reduction of excise duties on tobacco, alcohol and fuel".

\section{Research Methodology}

The first part of the paper will illustrate the current situation, related to the subject of research, namely the evolutions in time of fiscal pressure, shadow economy and corruption. Six European Union member states were selected for study: Romania, Poland, Croatia, Austria, Slovakia and Greece. The reason for choosing these countries is due to the fact that it was intended to include in the study developed and emerging countries from South-Eastern European Union. Thus, three countries in each category were selected, according to the International Monetary Fund (IMF) classifications of 2018 [19], namely: emerging countries - Romania, Poland, Croatia and developed countries Austria, Greece and Slovakia.

The data used in the research was taken from the European Commission- Eurostat databases, the International Monetary Fund, the Corruption Perception Index was taken from the International Transparency Non-Governmental Organization database, and data regarding shadow economy was taken from Friedrich Schneider's studies, through which he conducted measurements of this phenomenon in 157 countries over the period 
1999-2013; but also in 36 states, between 2003 and 2016. The data used in this study is annual data.

In the second part of the article, our study will be concretized by analyzing the relationship between tax burden, corruption and fiscal evasion, using the statistical analysis program for social sciences SPSS. Given that data on shadow economy is only available until 2016, there is a certain time limitation, so the analysis will be carried out over a period of 18 years, namely 1999-2016. The study will involve comparing the results obtained in the six countries, focusing on their grouping, according to the level of development. The tax burden will be calculated as the ratio between tax revenue of the state and gross domestic product, the shadow economy will be expressed as a percentage of GDP and the corruption perception index will be expressed as a score.

\section{Evolutions and General Considerations}

Within this section, the general evolution of the six countries undergoing research, over the period 1999-2016, will be studied using descriptive and comparative methods.

\subsection{Evolution of the tax burden in the period 1999-2016}

Figure 1 shows the tax burden trajectory, expressed as a percentage and calculated as the ratio between tax revenue and gross domestic product.

As can be seen in the Figure 1, Austria has the highest tax burden over the years under study, standing above the European Union average, with values ranging from 41.51 percent to 45.36 percent of GDP. Being a state with a high level of development and with living standards superior to the other countries, the high level of fiscal pressure is mainly due to the high tax rates the country use, precisely in order to have a low budget deficit, as well as a balanced budget. This would be difficult to achieve if the financial income and, implicitly, the tax rates would be low, given the high quality level of public services that the Austrian government provides to its citizens.

The next country with an increased tax burden is Croatia. The fiscal pressure during the analyzed period ranges from 35.16 percent in 2011 to 37.86 percent in 2016 . As a developing country, according to the IMF classification, the high rate of taxation can be mainly caused by a heavy fiscal pressure of the income tax. However, the high tax burden on this tax may have negative consequences, with repercussions on general welfare, for example: it discourages employers from creating new jobs, stimulates job 


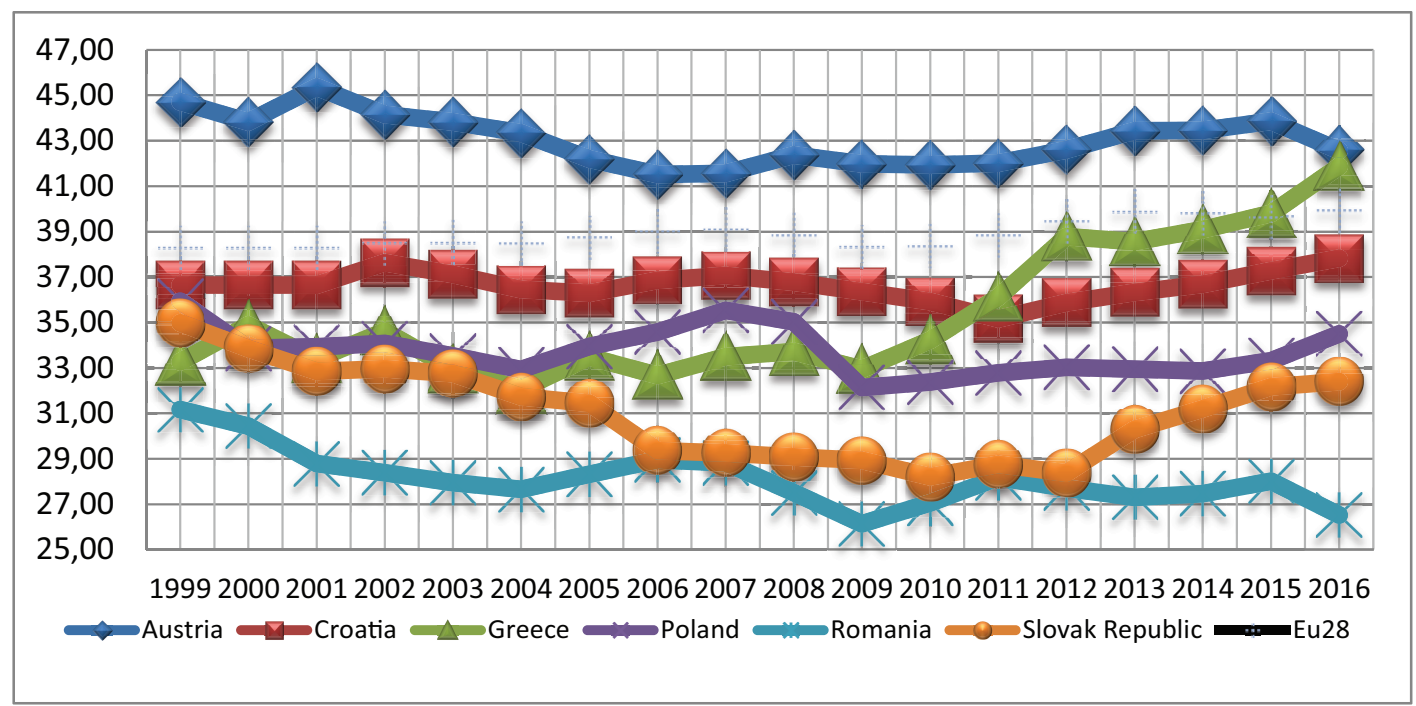

Figure 1: The evolution of tax burden, at the level of the six countries from South Eastern European Union (Source: authors`own work, based on Eurostat database).

cuts in times of recession, and boosts employment in the sector of shadow economy, according to Deskar-Skrbic et al. [10].

Greece has had an interesting evolution during the 18 years studied. After 2009, the year with deep traces left by the economic and financial crisis debut in 2008 , the overall fiscal pressure followed an upward trajectory, quite fast, increasing by 6.5 percentage points by 2012 (38.78\%), versus 2009, and the maximum of 41.87 percent was reached in 2016. This significant increase was mainly due to the fiscal reforms adopted to diminish the damaging effects of the financial crisis, which in the case of Greece led to an increase in public debt. Thus, Greece has undertaken to cut spending, increase in taxes and an ambitious implementation of a structural reform program [21], so as to achieve budgetary balance.

In the case of emerging countries, respectively in Poland and Romania, the evolution of the fiscal pressure is an oscillating one, below the average of the member states of the European Union. As it can be seen, Romania is at the bottom of the chart, with a decrease in the level of taxation after 2007, year of joining the European Union, a decrease, on the one hand, due partly to the emergence of the economic crisis, and on the other hand, the alignment of the Romanian fiscal policy with the European tax regulations [8]. The tax burden registered in Slovakia overlapped in seven years with that of Romania, namely 2006-2012; and after these years, the countries followed different trajectories: Romania has followed a downward trend of fiscal pressure, while Slovakia has an ascendant one. As far as the situation in Poland is concerned, its 
degree of taxation is close to the level of developed countries and this only reinforces the willingness of taxpayers to hide in the shadow economy [22].

\subsection{The evolution of the shadow economy and corruption percep- tion index}

Based on Schneider's research, Figure 2 shows the evolution of the shadow economy, expressed as a percentage of gross domestic product, for the six countries under review.

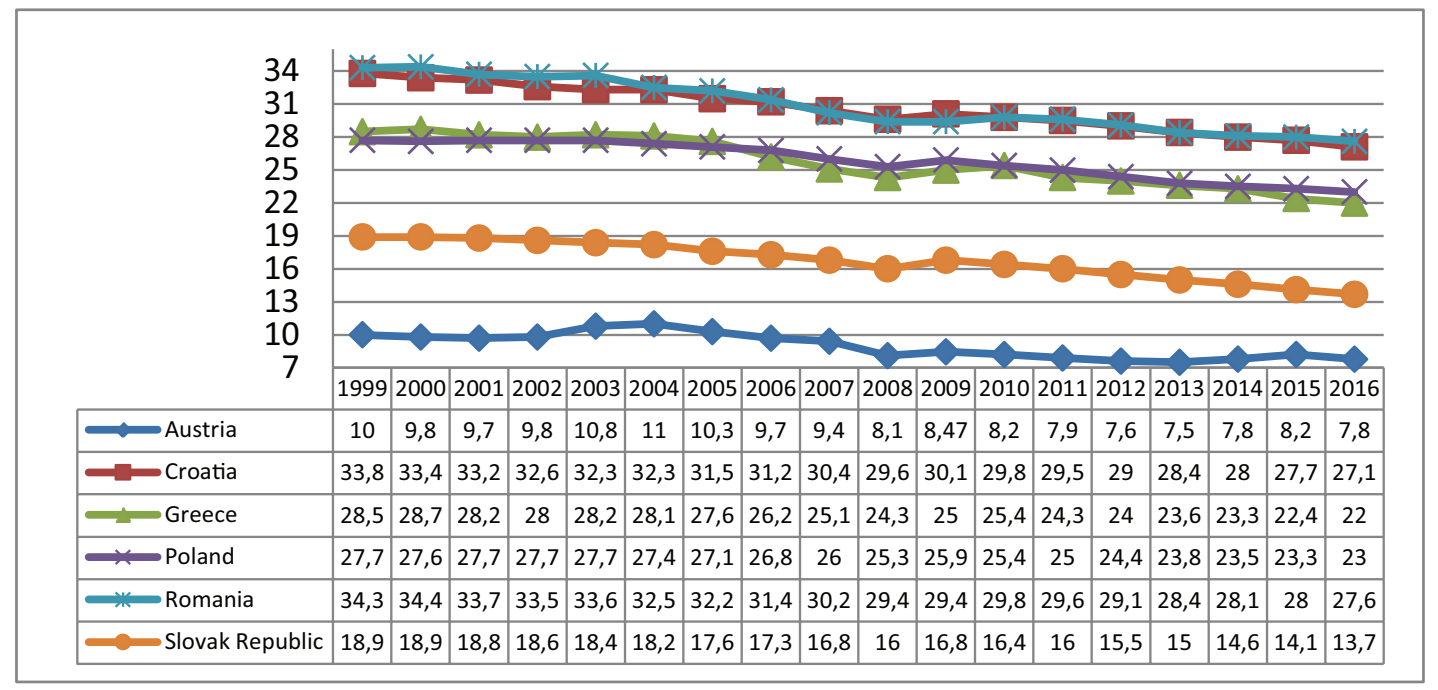

Figure 2: The evolution of shadow economy, at the level of the six countries from South Eastern European Union (Source: authors` own work, based on Schneider's research [26, 27]).

As can be seen, Romania and Croatia have a high shadow economy, more than 30 percentage points in GDP, but in a slight decline since 1999 and until 2008, when the underground economy reached 29.6 percent in Croatia, respectively 29.4 percent in Romania. It is obvious that the downward trend stopped in 2008 and overturned in 2009-2010, when the economic recession began, a downward trend which later recovered until 2016. Greece and Poland have followed a similar trend in the 18-years study, with values ranging from 22 percent to 28 percentage points. And for these countries, the years 2008-2010 had oscillations followed by a slight and steady decrease until 2016. The lowest rates of the shadow economy are found in Slovakia and Austria, developed countries. However, the percentage difference of the underground economy recorded in Austria is well below that in Slovakia, accounting between 7.5 percent and 11 percentage points of gross domestic product. By analyzing Austria's situation, with reference to the existing high fiscal pressure and the low rate of shadow economy in GDP, it seems that in this situation, the degree of taxation does not encourage tax evasion, according to other studies conducted like Torgler et al. [28]. 
The data referring to the corruption perception index used in Figure 3 have been taken from the non-governmental International Transparency Organization`s database, which has as its primary objective the prevention and combating of corruption at international level through research, documentation, information, education and public awareness activities, since 1993.

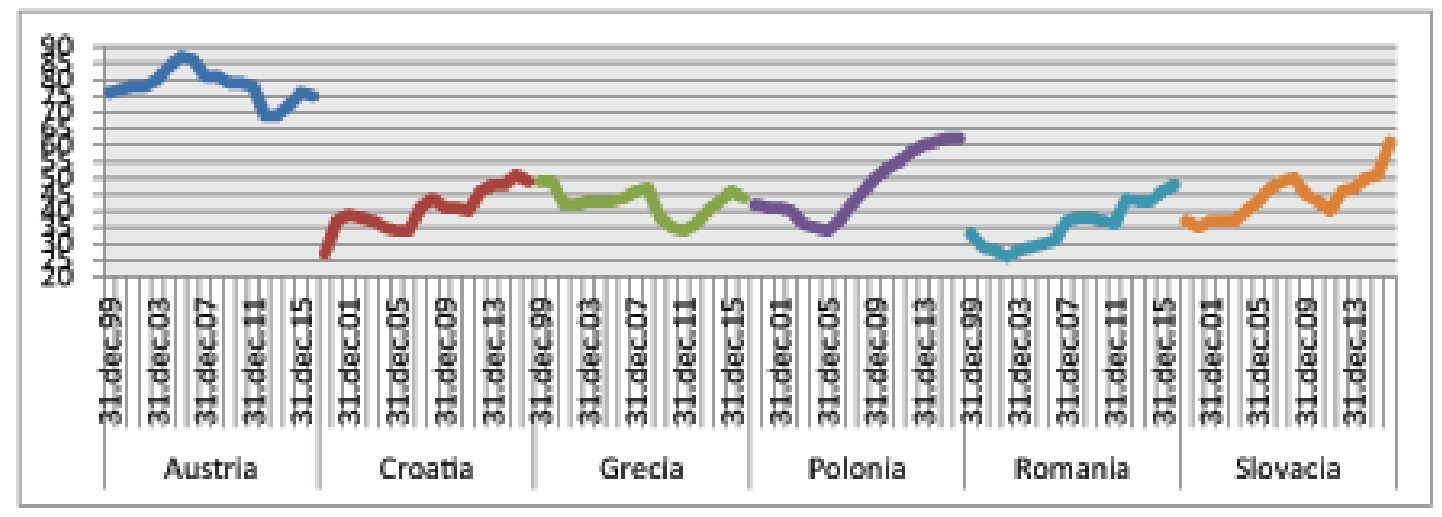

Figure 3: The evolution of corruption perception index, at the level of the six countries from South Eastern European Union (Source: authors` own work, based on Transparency International database [29]).

Corruption perception index is the perceived level of corruption in a country, established by assessments of global surveys. The CPI currently measures the level of corruption in 176 countries on a scale of 100 (non-existent corruption) to 0 (a very high degree of corruption). According to the International Transparency Organization, corruption means the improper use of public power in order to obtain private benefits [29].

The lowest level of corruption, as shown above can be found in Austria, with a maximum of 87 points in 2005 and a minimum of 69 points in 2012, which by 2016 followed again an upward trend. The most obvious rise in the index is in the case of Poland, with the CPI doubling its value from 2004 to 2016, which highlights a decrease in the level of corruption in this country. In the same situation, respectively the decrease of corruption is also Slovakia. Romania is characterized by a low level of CPI, namely a high corruption, but still declining since 2002. Romania, Greece and Croatia are below the mid-point of the interval, for example, below 50 points, which highlight the existence of corruption at a fairly high level. 


\section{The Relationship between Corruption, Shadow Econ- omy and Tax Burden}

Starting from the fact that the application of high taxes, fees and social security contributions has negative effects (such as on economic development, direct investment, labor force, etc.), the empirical analysis of this paper seeks to: first of all, identifying the correlation between corruption and tax evasion, in this paper referring to the shadow economy indicator, and second, identifying the degree of influence exerted by the tax burden on the phenomenon of shadow economy.

In order to achieve the proposed objectives, the aforementioned phenomena were analyzed with the help of the SPSS software, through which the following steps were taken:

1. has been analyzed the correlation between corruption and the shadow economy, at the level of the selected countries;

2. has been analyzed the correlation between the tax burden and the shadow economy (expressed as a percentage of GDP);

3. with the help of multiple linear regression, the relationship between corruption and the shadow economy, as well as the tax burden and the shadow economy, was study, at the level of the developed countries, as well as at the level of the emerging countries.

Tax burden in the analyzed countries is calculated as the ratio between total tax revenues and gross domestic product, the shadow economy is expressed as a percentage of GDP. Given that the corruption perception index is expressed as a score (the value 0 corresponds to the statement 'very corrupt' and the value 100 corresponds to 'non-existent corruption'), in order to analyze the existing correlations, we will use the following equation (1):

$$
\text { Corruption }=100 \text {-- Corruption Perception Index }
$$

In this way, the countries where will be recorded large values of this indicator, are characterized by a high level of corruption and vice versa.

The analyzed period is 18 years, namely 1999-2016. The data was taken from the Eurostat database, from the non-governmental International Transparency Organization's database and data regarding on the shadow economy was taken from Friedrich Schneider`s studies [26, 27]. 
In order to see if there is a link between the fiscal pressure, corruption and the shadow economy, Table 1 obtained in the SPPS program, allows the Pearson correlation $(R)$ to be analyzed.

TABLE 1: Analysis of the correlation between the tax burden, corruption and shadow economy.

\begin{tabular}{|c|c|c|c|c|}
\hline & & Tax burden & Shadow economy & Corruption \\
\hline \multirow[t]{3}{*}{ Tax burden } & $\begin{array}{l}\text { Pearson } \\
\text { Correlation }\end{array}$ & 1 &,$- 552^{* *}$ &,$- 682^{* *}$ \\
\hline & Sig. (2-tailed) & & ,000 & ,000 \\
\hline & $N$ & 108 & 108 & 108 \\
\hline \multirow[t]{3}{*}{ Shadow economy } & $\begin{array}{l}\text { Pearson } \\
\text { Correlation }\end{array}$ &,$- 552^{* *}$ & 1 &, $819^{* *}$ \\
\hline & Sig. (2-tailed) &, 000 & & ,000 \\
\hline & $\mathrm{N}$ & 108 & 108 & 108 \\
\hline \multirow[t]{3}{*}{ Corruption } & $\begin{array}{l}\text { Pearson } \\
\text { Correlation }\end{array}$ &,$- 682^{* *}$ & ,819** & 1 \\
\hline & Sig. (2-tailed) &, 000 & ,000 & \\
\hline & $\mathrm{N}$ & 108 & 108 & 108 \\
\hline
\end{tabular}

Source: own processing in SPSS software

Taking into account the link between the tax burden and the shadow economy, it can be noticed that the value of Sig is 0.00 in all cases, respectively $p<0.1$, meaning that there is a statistically significant correlation between the analyzed variables and the null hypothesis is rejected. Given that $R=-0.552$ in the case of tax burden and shadow economy, namely $R=-0.682$ in the case of tax burden and corruption, according to Hopkins, the values between 0.5 and 0.7 show a large connection between the variables [23], but negative in our case. The coefficient of determination $R^{2}=0.304$ and $R^{2}=0.465$ expresses a large effect, which can be concluded as follows: 30.4 percent of the spread of the shadow economy variable can be explained by the scattering of the tax burden variable, respectively 46.5 percent of the scattering of the variable tax burden can be explained by the scattering of the corruption variable. Taking into account the link between corruption and the shadow economy, also in this case the value of $\mathrm{Sig}$ is 0.00 and the $R$ value of 0.819 shows a strong significance between the variables. The value of $R^{2}=0.67$ indicates that 67 percent of the scatter of the shadow economy variable can be explained by the scattering of the corruption variable.

Considering that there is a significant correlation between the variables, to identify the effects of corruption on the shadow economy, but also the effects of fiscal pressure on the shadow economy, the 'Enter' method in the SPSS software was used. This procedure involves the introduction of all variables in the model, regardless of the 
statistical significance. However, in order to highlight the existing correlations, we will only accept in the model those independent variables, which have the highest statistical significance, namely the $p$ value $<0.1$. We chose to make two models of multiple linear regression, in which we had a dependent variable namely: the shadow economy (hereinafter Shadow_economy); and two independent variables: corruption (hereinafter referred as Corruption) and tax burden (noted as TaxBurden). In order to observe the degree of influence of the independent variables on the dependent variable, the determination coefficient $R^{2}$ will be taken into account.

In Table 2, the relationship between the dependent variable 'Shadow_economy' and the independent variable 'Corruption' is studied for the six countries analyzed in the first part of the paper. In order for the variables to be included in the model, Sig needs to be less than $\alpha(\alpha=0.1)$. The regression equation (2) has the following form:

$$
Y=\beta * X+\alpha
$$

where:

$-\mathrm{Y}$ is the dependent variable;

- X represents the independent variable;

$-\alpha$ is the free term of the regression line (value for $X=0$ );

- $\beta$ is the regression coefficient (the amount with which $Y$ changes when $X$ changes with one unit).

TABLE 2: Analysis of the relationship between corruption and shadow economy.

\begin{tabular}{|c|c|c|c|}
\hline Country & Regression equation & $\mathbf{R}^{2}$ & Sig value \\
\hline Austria & Shadow_economy $=-0,156 *$ Corruption $+12,432$ & 0,45 & 0,02 \\
\hline Grecia & 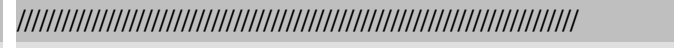 & 0,07 & 0,27 \\
\hline Slovacia & Shadow_economy $=0,221^{*}$ Corruption $+4,393$ & 0,76 & 0,00 \\
\hline România & Shadow_economy $=0,314^{*}$ Corruption $+10,708$ & 0,84 & 0,00 \\
\hline Polonia & Shadow_economy $=0,157^{*}$ Corruption $+17,597$ & 0,88 & 0,00 \\
\hline Croaţia & Shadow_economy $=0,293^{*}$ Corruption $+13,155$ & 0,77 & 0,00 \\
\hline
\end{tabular}

Source: own processing in SPSS software

According to Tabel 2, the shadow economy is influenced by corruption in 5 of the 6 analyzed countries. It can be noticed that in all cases of emerging countries, but also in the case of two developed countries, the variable 'Corruption' is accepted. The value of Sig $=0.00$ and $R^{2}>75$ percent in Slovakia, Romania, Poland and Croatia, highlights the statistically significant influence of corruption on the shadow economy. In Romania, for example, modifying a unit of corruption will lead to a change of 0,314 percentage points, in the same sense, of the fiscal evasion. This is applies also for Slovakia, Poland and 
Croatia, where by analyzing the regression equations, the link between the variables is positive, directly proportional. This translates into the fact that an increase in the phenomenon of corruption in these countries has a strong influence on the growth of the shadow economy, respectively tax evasion. Taking into account that three of the four countries in which this situation is found are emerging countries, we can say that the level of precarious development favors the emergence of corruption and directly favors the emergence of the shadow economy. The only exception is in Austria, a developed country, where the link between corruption and the shadow economy is inversely proportional. This can be associated with a decrease in the underground economy, as corruption increases. Thus, high corruption is not a reason to hide in the shadow economy, because it only encouraging the taxpayer to resort to corruption instruments, so as to gain economic, financial, social benefits, etc. through which he can operate in the registered economy.

Table 3 examines the relationship between the dependent variable 'Shadow_ economy' and the independent variable 'TaxBurden'.

TABLE 3: Analysis of the relationship between tax burden and shadow economy.

Country
Austria
Grecia
Slovacia
România
Polonia
Croaţia

Regression equation
||||||||||||||||||||||||||||||||||||||||||||||||||||||||||||||||||||||||||||||||
Shadow_economy= -0,598*TaxBurden+ 46,833
Shadow_economy= 0,362*TaxBurden+ 5,530
Shadow_economy= 1,360*TaxBurden - 7,406
|||||||||||||||||||||||||||||||||||||||||||||||||||||||||||||||||||||||||||||||||||
||||||||||||||||||||||||||||||||||||||||||||||||||||||||||||||||||||||||||||||

\begin{tabular}{|l|}
\hline $\mathbf{R}^{2}$ \\
0,09 \\
0,61 \\
0,19 \\
0,51 \\
0,08 \\
0,00 \\
\hline
\end{tabular}

Sig value

0,22

0,00

0,07

0,01

0,23

0,96

Source: own processing in SPSS software

According to Table 3, the shadow economy is influenced by the tax burden in 3 of the 6 analyzed countries. For developed countries, Greece and Slovakia, the value of Sig is less than 0.1 percent, so the independent variable is accepted. The $R^{2}=61$ percent determinant in Greece shows a significant influence, while $R^{2}$ of 19 percent in Slovakia underlines the low importance of the power exerted by the fiscal pressure on the shadow economy. It can be noticed that in the case of emerging countries, only Romania accepts the 'TaxBurden' variable, with Sig= 0.01 and $R^{2}=51$ percent. In these three countries there is a positive direct relationship between these two variables. For example, in Romania, the increase with a percentage unit of tax burden leads to an increase of 1.36 percentage points of the shadow economy, being a determining factor for taxpayers, to avoid paying tax liabilities. 
In the emerging countries, respectively in Poland and Croatia, this variable is not accepted, the value of Sig value being greater than 0.1, which can be translated into the fact that the fiscal pressure does not have a significant influence on the increase or decrease of the shadow economy. Austria, on the other hand, is the only state of the developed countries, which does not accept the tax pressure variable in the model. This suggests, as seen in Figure 2, that the level of tax evasion in this country is at the lowest level among all the analyzed countries and from Figure 1 presented in this paper, Austria holds the highest proportion of tax revenues in GDP. This may highlight that the low underground economy in this country is not influenced by the magnitude of tax revenue in gross domestic product and the government uses this revenue rationally and does not encourage the taxpayer to hide in the informal economy.

By comparing the Table 2 and 3, for the three countries that do not accept the 'TaxBurden' independent variable, respectively Austria, Poland and Croatia, the significant effects on the shadow economy are generated by the corruption phenomenon rather than by the underground economy. But in addition to corruption, in the case of emerging countries, there may be other important factors that encourage tax evasion and may be directly related to the level of economic development, which, in turn, influences the pernicious phenomena in the state's economy.

\section{Conclusions}

The objective of this research was the empirical determination of the relationship between two phenomena harmful for the economic and fiscal existence of the state, namely the corruption and the shadow economy, as well as the analysis of the relation between the tax burden and the underground economy.

The results obtained by this study are in line with those obtained in the previous researches and there are relations of influence between the analyzed variables. The six countries of Southeast Europe are characterized by a tax evasion directly influenced by both corruption and tax burden. This means that the development of activities in the shadow economy is encouraged and becomes attractive for those who seek to avoid paying taxes and duties.

As ways to increase the payment compliance, but also to stop these evasion phenomena, would be: the existence of a stable fiscal system, by creating improvements in the fiscal policies, at the level of the control bodies, acting by the power of example, but also at the level of public services provided to taxpayers; as well as the existence of national anti-corruption programs, by increasing professionalism and transparency 
at government level. The more staff in the tax administration institutions and from the administration institutions will adopt a fair, transparent, tax-oriented and corruption-free behavior, the better things will go and the trust of the citizens in the control bodies, as well as those in the state power, will increase. This will only encourage legitimate activities, without tax evasion, which will result in increases in state revenues.

Taking into account the statistical data limited in terms of the time period, but also in terms of the number of studied countries, focusing on the present paper at only six countries from South East Europe, a future research direction would require a thorough study of the situation of all the Member States of the European Union. This would involve taking into account other factors that may influence the emergence of the evasion phenomenon, such as unemployment rate, average wage levels, foreign investment, inflation, but also political governance.

\section{References}

[1] Achim, M. V. (2017). Corruption and the Underground Economy - Theories and Studies, Clujean University Press, Cluj- Napoca, Romania, http://www.editura. ubbcluj.ro/bd/ebooks/pdf/2119.pdf, last accessed on 14.03.2019.

[2] Achim, M. V., Borlea, S. N., Găban, L. V., et al. (2018). Rethinking the shadow economy in terms of happiness. Evidence for the European Union Member States, Technological and Economic Development of Economy, 24(1), 199-228.

[3] Albulescu, C. T., Tămășilă, M. and Tăucean, I. M. (2016). Entrepreneurship, tax evasion and corruption in Europe. Procedia-Social and Behavioral Sciences, 221, 246-253.

[4] Bizna, A. M. (2017). Dimensions, characteristics and main forms of manifestation of informal economy in Romania, The National Institute Of Economic Research, Collection Economic Library, Economical issues Series, Volume 441, Center for Economic Information and Documentation Publisher House, Bucharest, http: //www.ince.ro/Publicatii/Publicatii_online/publicatii_online.html, last accessed on 14.03.2019.

[5] Bizna, A. M. (2017). Evaluation of Informal Economy- corruption and tax evasion, The National Institute Of Economic Research, Collection Economic Library, Studies and Economic research Series, Volume 110, Center for Economic Information and Documentation Publisher House, Bucharest, http://www.ince.ro/Publicatii/ Publicatii_online/publicatii_online.html, last accessed on 14.03.2019.

[6] Braşoveanu, I. V. and Obreja Brasoveanu, L. (2009). Correlation between Corruption and Tax Revenues in EU27, Economic Computation and Economic Cybernetics 
Studies and Research, 43(4), 133-142.

[7] Cărăuș, I. G., Cărăuş, M. and Stanese, I. T. (2016). Tax Evasion under the Influence of Fiscal Policy Measures, Annals-Economy Series, 4, 98-102.

[8] Cristea, L. A. and Vodă, A. D. (2018). The correlation between fiscal revenues of Romania and gross domestic product in the last 12 years. Annals of the University of Oradea, Economic Science Series, 27(2), 84-93.

[9] Dinga, E. (2008). Theoretical considerations on tax evasion vs. tax fraud, Financial Studies from Centre of Financial and Monetary Research 'Victor Slavescu', Vol. 12, issue $4,20-50$.

[10] Deskar-Škrbić, M., Drezgić, S. and Šimović, H. (2018). Tax policy and labour market in Croatia: effects of tax wedge on employment. Economic research, 31(1), 1218-1227.

[11] European Commission (2015). Final Communication from the Commission to the European Parliament and the Council on tax transparency to fight tax evasion and avoidance, https://eur-lex.europa.eu/legal-content/EN/TXT/?uri= celex[\%]3A52015DC0136 last accessed on 14.03.2019.

[12] European Commission (2017). Special Eurobarometer 470- Corruption Report Survey, http://ec.europa.eu/commfrontoffice/publicopinion/index.cfm/ResultDoc/ download/DocumentKy/81008, last accessed on 14.03.2019.

[13] European Commission -- Taxation and Customs Union. "The fight against tax fraud and tax evasion - Time to get the missing part back. https://ec.europa.eu/ taxation_customs/fightagainst-tax-fraud-tax-evasion/missing-part_en

[14] Fedajev, A. and Arsić, M. (2017). Drivers of shadow economy in transition countries during the post-crisis period: The results of structural model. FIKUSZ'17 Proceedings, 19.

[15] Fedotenkov, I. (2019). Corporate labour share of income and the shadow economy: a cross-country analysis, Applied Economics Letters, 26:4, 302-305, DOI: 10.1080/13504851.2018.1467549.

[16] Feld, L.P. and Schneider, F. (2010). Survey on the shadow economy and undeclared earnings in OECD countries. German Economic Review, 11(2), 109-149, DOI: 10.1111/ j.1468-0475.2010.00509.x.

[17] Hassan, M. and Schneider, F. (2016). Size and Development of the Shadow Economies of 157 Countries Worldwide: Updated and New Measures from 1999 to 2013, IZA Discussion Papers 10281, Institute for the Study of Labor.

[18] Hetemi, A., Konxheli, D., Gulhan, O., et al. (2018). Factors of the Shadow Economy in the Republic of Albania. EuroEconomica Journal, 37(3). 
[19] International Monetary Fund (2018). World Economic Outlook: Cyclical Upswing, Structural Change. Washington, DC, April.

[20] Law 241/2005 on preventing and combating tax evasion, Official Gazette of Romania

[21] Matsaganis, M., Leventi, C. and Flevotomou, M. (2012).The Crisis and Tax Evasion in Greece: What are the Distributional Implications? CESifo Forum, Vol. 13, No. 2, 26-32.

[22] Mozylowski, P. and Kalinowska, K. (2014). The Gray Zone in Poland-Phenomenon, Conditions and Causes, Multifaceted Consequences. International Journal of Economics and Business Administration, 2(3), 15-26.

[23] Noaghi, S. and Dura C. (2018). Elemente de statistică aplicată- Elements of applied statistics, Risoprint Publishing House, Cluj Napoca, România

[24] Osmani, R. (2015). The level of the shadow economy, tax evasion and corruption: The empirical evidence for SEE countries. Seeu Review, 11(2), 6-22.

[25] Remeikienè, R., Gasparènienè, L., Chadyšas, V. et al. (2018). Identification of the shadow economy determinants for the Eurozone member states: application of the MIMIC model. Journal of business economics and management, 19(6), 777-796.

[26] Schneider, F. and Buehn, A. 2012. Shadow Economies in Highly Developed OECD Countries: What Are the Driving Forces?, IZA Discussion Paper no. 6891.

[27] Schneider, F. (2016). Estimating the size of the shadow economies of highlydeveloped countries: selected new results, CESifo DICE Report, 14(4), 44-53.

[28] Torgler, B., Schneider, F. and Schaltegger, C. A. (2010). Local autonomy, tax morale, and the shadow economy. Public Choice, 144(1-2), 293-321.

[29] Transparency International, https://www.transparency.org, last accessed on 16.03.2019

[30] Ungureanu, M. A., Calugareanu, M., Caraus, M. et al. (2016). Conceptual approaches to tax evasion in Romania. Romanian Economic and Business Review, 11(3), 7-14.

[31] Virta, H. (2007). Corruption and Shadow Economy: Differences in the Relationship between Countries. Discussion papers, Helsinki Center of Economic Research, 171, 1- 26.

[32] Virta, H. (2010). The linkage between corruption and shadow economy size: does geography matter?, International Journal of Development Issues, Vol. 9 Issue: 1, 4-24. 